\title{
Lansky Performance Status 10
}

National Cancer Institute

\section{Source}

National Cancer Institute. Lansky Performance Status 10. NCI Thesaurus. Code C70539.

No play; does not get out of bed. 